\title{
基于环境库兹涅茨曲线的我国大气污染防治重点区域 环境空气质量与经济增长关系研究
}

\author{
李 竞 ${ }^{1,2}$, 侯丽朋 ${ }^{1,2}$, 唐立娜 ${ }^{1, *}$ \\ 1 中国科学院城市环境研究所城市环境与健康重点实验室,厦门 361021 \\ 2 中国科学院大学,北京 100049
}

摘要:改革开放以来, 中国经济迅猛发展,但大气污染等环境问题日益突出。进人 21 世纪,我国通过颁布实施多项大气污染防 治政策,将京津冀及周边地区、长三角地区、珠三角地区等大气污染较严重的区域划定为重点区域,针对性制定治污措施和实施 减排工程,努力推动区域环境空气质量改善。基于 2000-2019 年我国 31 个省 (自治区、直辖市) (以下简称 31 个省份) GDP,以 及 $\mathrm{SO}_{2} 、 \mathrm{PM}_{10} 、 \mathrm{NO}_{2}$ 三项大气污染物浓度数据,利用环境库兹涅茨曲线 ( EKC,Environmental Kuznets Curve) 模型,对 31 个省份和京 津冀及周边地区、长三角地区、珠三角地区的经济增长情况、大气污染物浓度演变以及二者之间的关系进行了系统全面的分析 评估。研究结果显示: (1) 近年来实施的各项大气污染防治政策,特别是 2013 年以来颁布实施的《大气污染防治行动计划》《打 赢蓝天保卫战三年行动计划》,推动环境空气质量改善的同时,促进了经济发展与环境保护长期关系协调性逐步增强,除 $\mathrm{NO}_{2}$ 浓 度呈 $\mathrm{U}$ 型外, 31 个省份 $\mathrm{SO}_{2}$ 浓度、 $\mathrm{PM}_{10}$ 浓度与人均 $\mathrm{GDP}$ 的 $\mathrm{EKC}$ 曲线呈倒 $\mathrm{U}$ 型和倒 $\mathrm{N}$ 型, 并处于快速下降阶段。(2) 京津冀及 周边地区 $\mathrm{SO}_{2}$ 浓度与人均 $\mathrm{GDP}$ 呈倒 $\mathrm{U}$ 型, 且处于快速下降阶段; $\mathrm{PM}_{10}$ 和 $\mathrm{NO}_{2}$ 浓度均呈现 $\mathrm{U}$ 型关系, 且均处于上升期。(3) 长三 角地区 $\mathrm{SO}_{2} 、 \mathrm{PM}_{10}$ 浓度与人均 $\mathrm{GDP}$ 呈现倒 $\mathrm{U}$ 型和 $\mathrm{U}$ 型, 但均处于下降阶段; $\mathrm{NO}_{2}$ 浓度与人均 $\mathrm{GDP}$ 无相关关系。(4) 珠三角地区 $\mathrm{SO}_{2} 、 \mathrm{PM}_{10}$ 和 $\mathrm{NO}_{2}$ 浓度与人均 GDP 均呈现倒 $\mathrm{U}$ 型关系,且均处于下降阶段。为此, 建议 “十四五” 期间我国政府要继续实施新一 轮的大气污染防治行动计划, 聚焦机动车 $\mathrm{NO}_{x}$ 污染管控, 大力推动 $\mathrm{NO}_{2}$ 浓度稳步下降, 以实现我国环境空气质量持续改善, 为统 筹经济高质量发展和生态环境高水平保护奠定坚实基础。

关键词: 环境库兹涅茨曲线;大气污染防治重点区域;经济增长;环境空气质量

\section{Relationship between air quality and economic growth in key areas of air pollution control in China based on the Environmental Kuznets Curve}

\author{
LI Jing ${ }^{1,2}$, HOU Lipeng ${ }^{1,2}$, TANG Lina ${ }^{1, *}$ \\ 1 Key Laboratory of Urban Environment and Health, Institute of Urban Environment, Chinese Academy of Sciences, Xiamen 361021, China \\ 2 University of Chinese Academy of Sciences, Beijing 100049, China
}

\begin{abstract}
Since the reform and opening-up, China's economy has obtain rapid development. However, the environmental problems in China such as air pollution have become increasingly prominent. In the 21 st century, a number of air pollution prevention and control policies were promulgated by the Chinese government, while the serious air polluted areas such as the Beijing-Tianjin-Hebei and its surrounding areas, the Yangtze River Delta region and the Pearl River Delta region were designated as key areas of air pollution control. To improve the regional air quality, pollution control measures and emission reduction projects have been implemented. This research uses the Environmental Kuznets Curve (abbreviated as EKC) to
\end{abstract}

基金项目: 国家重点研发计划课题(2016YFC0502902)

收稿日期: 2021-05-12; 接收日期: 2021-09-28

* 通讯作者 Corresponding author.E-mail: lntang@iue.ac.cn

\#本研究采用数据均不包含港澳台相关数据 
analyze the economic growth, the trend of atmospheric pollutants concentration and the relationship between the two in China and the key areas of air pollution control, based on the GDP and the concentration of $\mathrm{SO}_{2}, \mathrm{PM}_{10}$, and $\mathrm{NO}_{2}$ in $\mathrm{China}^{\prime}$ s 31 provinces from 2000 to 2019. The results show that: (1) the air pollution prevention and control policies in recent years, especially the Action Plan for the Prevention and Control of Air Pollution and The Three-year Action Plan to Beat Air Pollution, have significantly improved the air quality and the relationship between economic development and environmental protection since 2013. The EKC of GDP per capita and $\mathrm{SO}_{2}$ concentration is inverted U-shape while that of $\mathrm{PM}_{10}$ concentration is inverted $\mathrm{N}$-shape, both in a rapid decline phase. However, the EKC of GDP per capita and $\mathrm{NO}_{2}$ concentration is U-shape. (2) The EKC of GDP per capita and $\mathrm{SO}_{2}$ concentration in the Beijing-Tianjin-Hebei and its surrounding areas is an inverted $\mathrm{U}$-shape, being in a rapid decline phase while those of $\mathrm{PM}_{10}$ and $\mathrm{NO}_{2}$ concentrations are both U-shape with an upward trend. (3) The EKC of GDP per capita and $\mathrm{SO}_{2}$ and $\mathrm{PM}_{10}$ concentration in the Yangtze River Delta region are inverted U-shape and U-shape respectively, both in a decline phase. Yet the $\mathrm{NO}_{2}$ concentration has no correlation with GDP per capita. (4) The EKC of GDP per capita and the three pollutants concentration in Pearl River Delta region are all inverted U-shape, being in a decline phase. Therefore, it is recommended that the Chinese government launches new air pollution control plans which focus on the control of $\mathrm{NO}_{x}$ production by motor vehicles for the continuous decline of $\mathrm{NO}_{2}$ concentration. All the efforts will lead to high-quality economic development and high-level protection of the ecological environment during the "14th Five-Year Plan" period.

Key Words: Environmental Kuznets Curve; key areas of air pollution control; economic growth; air quality

改革开放以来, 我国经济迅猛发展, 这种快速增长一定程度上是以牺牲自然资源和环境为代价的。我国 的二氧化碳 $\left(\mathrm{CO}_{2}\right)$ 和能源消耗量分别于 2007 年和 2009 年超越美国, 成为世界最大的能源消耗和碳排放国 家 ${ }^{[1]}$ 。随之而来的是资源能源消耗过高, 环境质量明显恶化, 特别是空气污染日益严重 ${ }^{[2]}$ 。而京津冀、长三 角、珠三角地区成为我国大气污染最严重的三大区域,并从城市和局地污染发展成为影响范围更广、更不易控 制和治理的区域性污染 ${ }^{[3]}$ 。在经济高速增长和环境空气质量日趋恶化的复杂严峻形势下, 我国大气污染和 经济增长之间关系成了一个重要的研究问题。

大量研究表明经济增长与大气污染之间存在长期稳定的关系 ${ }^{[4-6]}$ 。学者们已应用多种经典模型实证了 经济增长与空气质量之间的数量关系, 其中环境库兹涅茨曲线 ( EKC, Environmental Kuznets Curve) 曲线是普 遍存在的规律 ${ }^{[7]}$ 。库兹涅茨曲线是 20 世纪 60 年代美国经济学家 Kuznets 提出一条倒 U 形曲线, 用以描述收 人差异和经济增长之间的关系。20 世纪 90 年代初期, 由美国环境经济学家 Grossman 和 Krueger 在大量的数 据分析和实证检验的基础上, 发现环境质量与经济增长之间也存在着随着人均收入提高环境先恶化后改善的 情况,从而引申出 $\mathrm{EKC}$ 曲线, 用以描述一个国家或区域环境质量与经济发展之间的相对关系变化趋势 ${ }^{[8]}$ 。 EKC 曲线理论提出后, 国内外学者关于经济、收人与环境之间的实证研究不断深人。从研究结果看, 部分研 究验证了经济增长或人均收人与大气污染之间呈现了符合 EKC 理论的倒 U 型曲线 ${ }^{[9-14]}$ 。随着研究的深人, 有部分学者认为曲线并不呈严格的倒 U 型, 也可能出现不一样的变化规律 ${ }^{[15-17]}$ 。在针对我国大气污染与经 济增长关系研究中, 从研究结果看, 不同学者针对不同区域研究得出倒 $U$ 型、 $U$ 型等 6 种不同类型的曲 线 ${ }^{[18-20]}$ 。从研究区域看, 多数研究以全国、省份和城市为单位进行研究 ${ }^{[21-26]}$, 部分针对我国传统意义上的经 济区域——东、中、西部进行研究 ${ }^{[27-30]}$, 仅有李健等 ${ }^{[31]}$ 、吴俊良 ${ }^{[32]}$ 研究涉及京津冀、珠三角城市群等具有相同 经济、社会或大气污染特征的若干省份形成的区域。从选取指标看,较多研究采用人均 GDP 表征经济增长, 对于表征大气污染的指标, 空气质量指数 (AQI 或 API), 污染物排放量和环境空气污染物浓度分别被不同研 究者使用 ${ }^{[33-35]}$ 。从研究时间范围看, 时间跨度以 10 年左右为主 ${ }^{[36-38]}$ 。

通过文献梳理发现,针对我国大气污染与经济增长之间关系的研究有以下几方面不足:

一是现有针对区域层面的研究较少,其中涉及兼具人口集中、经济发达、污染严重等多重特征的区域也较 
少。二是我国 AQI 由于受多种因素的影响, 常表现出与公众感受及其他环境监测指标不相一致的现象 ${ }^{[39]}$, 加 之生态环境部门一般仅将 AQI 作为向公众提供健康指引的工具。此外, 污染物排放量数据除真实性有待进 一步验证外, 也无法直接反应环境空气质量状况, 而大气中污染物浓度监测数据则相对客观, 是最直接影响人 体健康的变量, 更能真实反映经济增长与大气环境之间的关系 ${ }^{[40]}$ 。但只有部分研究采用了大气污染物浓度 的数据, 且其中多数研究仅有一小部分城市的数据。三是现有研究跨度均较短, 数据量覆盖 20 年及以上的研 究较少, 且目前最新数据仅更新到 2017 年。我国 2018-2019 年大气环境形势较 2017 年也发生了较大变化, 很有必要使用最新的监测数据来表征大气污染现状。

因此,本文基于 2000-2019 年 31 个省份地级及以上城市大气污染物浓度指标, 选取京津冀及周边地区、 长三角地区、珠三角地区等大气污染防治重点区域 (以下简称重点区域) 作为研究区域, 对其环境空气质量与 经济发展之间的关系进行研究。需要说明的是,污染物会随着空气流动而导致出现跨地区传输,一个地区污 染物浓度除受本地区污染排放直接影响外, 可能会受到周边污染物浓度较高的地区污染传输影响。鉴于本文 研究的区域范围较大, 除珠三角地区外, 均涉及多个省份, 即便存在污染传输, 主要影响区域也在与非重点区 域交界的省份或城市, 或传输通道部分城市, 对整个区域污染物平均浓度影响较小,因此产生决定性因素的仍 是该区域整体的污染物排放量。

\section{1 数据与方法}

\section{1 研究区域}

2013 年以来, 我国颁布实施的《大气污染防治行动计划》 ( 以下简称《大气十条》) 和《打赢蓝天保卫战三 年行动计划》 (以下简称《三年行动计划》) 先后将京津冀地区、长三角地区、珠三角地区、汾渭平原等地区列为 大气污染防治重点区域。以上重点区域涉及北京、天津、河北、山西、上海、江苏、浙江、安徽、山东、河南、广东、 陕西等 12 省份, 几乎涵盖了我国经济最为发达、人口分布最为集中的省份: 2019 年,北京、上海等 7 省份人均 GDP 位居全国前 10 , 上海、天津等 10 省份人口密度位居全国前 $10^{[41-42]}$ 。同时, 该区域也是我国大气污染较 严重的区域,其中京津冀及周边地区、汾渭平原的单位面积大气污染物排放量约为全国平均水平的 4 倍 ${ }^{[43]}$, 导致秋冬季极易引发雾霧, 人民群众反映强烈。可以说是经济发展、人体健康和生态环境之间矛盾最为突出 的地区。

为了便于数据分析统计, 本文根据《大气十条》《三年行动计划》划定的重点区域, 结合 “十四五” 期间大 气环境管理需求,将研究区域整合为三大重点区域,分别是 (1) 京津冀及周边地区,包含北京、天津、河北、山 西、河南、山东、陕西等 7 省份; (2) 长三角地区,包括上海、江苏、安徽、浙江等 4 省份; (3) 珠三角地区,包括广 东省。除以上 12 省份外,其余 19 省份统称为大气治理非重点区域 (以下简称非重点区域) (图 1)。

\section{2 数据来源和预处理}

本文选取我国 31 个省份 2000-2019 年人均 GDP 作为经济发展指标表征经济增长状况,GDP 和人口等 数据均来源于国家统计局官方网站。GDP 以 2000 年为基期, 按不变价格来计算, 以消除通货膨胀的影响。 选取 2000-2019 年 $\mathrm{SO}_{2} 、 \mathrm{PM}_{10}$ 和 $\mathrm{NO}_{2}$ 年均浓度表征环境空气质量 (表 1), 浓度数据来源于国家空气质量监测 站。由于环境空气质量指标和经济发展指标数量级不一致,本文采用取对数的计算方法消除指标间数量级不 一致导致回归分析后产生异方差问题。此外,2012 年和 2013 年我国先后颁布实施了新《环境空气质量标准》 (GB3095-2012) 和《环境空气质量评价技术规范》( HJ663-2013), 导致 2013 年与 2012 年城市污染物浓度 数据统计口径不一致, 为避免因统计口径变动导致数据出现非正常波动, 在分析污染物浓度年度变幅时不对 2013 年数据进行统计。

\section{3 研究方法}

$\mathrm{EKC}$ 模型中最具代表性的是二次多项式函数关系, 是目前国际上常用的简化计量模型:

$$
y=a+b_{1} x+b_{2} x^{2}+\varepsilon
$$




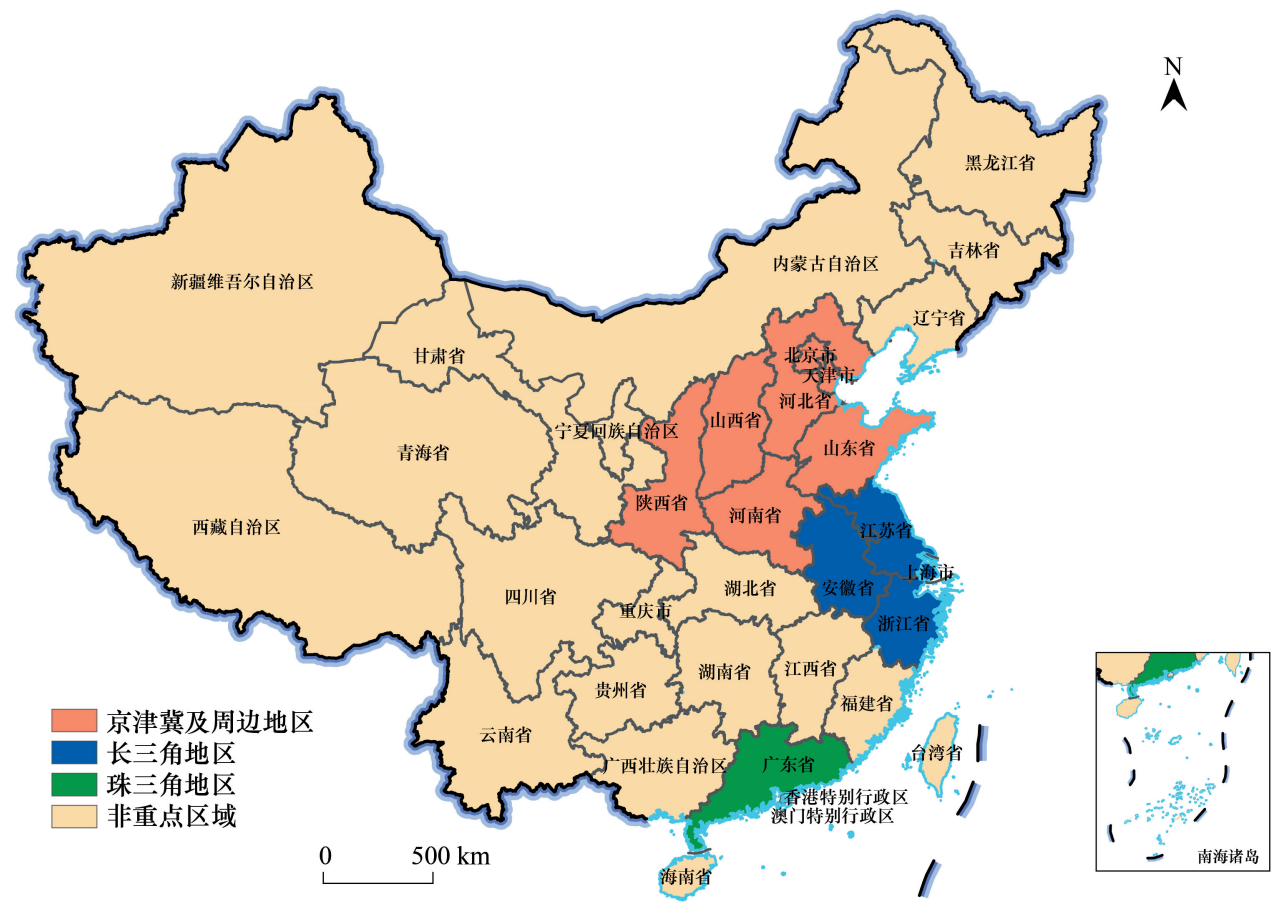

图 1 我国大气污染防治重点区域示意图

Fig.1 Sketch map of key regions of atmospheric governance in China

表 1 环境空气质量与经济增长环境库兹涅茨曲线分析指标

Table 1 Indicators of Environmental Kuznets Curve of the air quality and the economic growth

\begin{tabular}{|c|c|c|c|}
\hline 类型 & 选取指标 & 指标来源 & 指标说明 \\
\hline Types & Indicators & Resource of indicators & Definition of indicator \\
\hline 经济增长 Economic growth & 人均 GDP & $\begin{array}{l}\text { 国家统计局官方网站统计的 } 31 \\
\text { 个省(市、区) 年度 GDP 和人口 } \\
\text { 数据 }\end{array}$ & $\begin{array}{l}\text { GDP 以 } 2000 \text { 年为基期, 按不变价 } \\
\text { 格来计算, 以消除通货膨胀的影响 }\end{array}$ \\
\hline 环境空气质量 Air quality & $\begin{array}{l}\mathrm{SO}_{2} \text { 年均浓度 } \\
\mathrm{PM}_{10} \text { 年均浓度 } \\
\mathrm{NO}_{2} \text { 年均浓度 }\end{array}$ & 国家空气质量监测站 & \\
\hline
\end{tabular}

式中, $y$ 为环境压力指标; $x$ 为经济发展指标; $a$ 为常数项,通常表示国家或者地区的特征参数; $b_{1} 、 b_{2}$ 表示 $x$ 的一次和二次项系数, $\varepsilon$ 为随机误差项。Grossman 和 Krueger 将该模型进一步拓展为三次函数式 ${ }^{[44]}$ :

$$
y=a+b_{1} x+b_{2} x^{2}+b_{3} x^{3}+\varepsilon
$$

式中, $y$ 为环境压力指标; $x$ 为经济因素指标; $a$ 为常数项,通常表示国家或地区的特征参数; $b_{1} 、 b_{2} 、 b_{3}$ 表示 $x$ 的一次、二次和三次项系数, $\varepsilon$ 为随机误差项。

本文选取大气污染物浓度作为环境压力指标, 人均 GDP 作为经济增长指标, 采用三次对数函数分析我国 环境空气质量与经济增长之间的 EKC 曲线关系。若回归结果显示三次项系数不显著时, 选取二次多项式对 数函数进行回归。

$$
E_{\text {con }}=a+b_{1} G+b_{2} G^{2}+b_{3} G^{3}+\varepsilon
$$

式中, $E_{\text {con }}$ 代表 $\mathrm{SO}_{2} 、 \mathrm{PM}_{10} 、 \mathrm{NO}_{2}$ 浓度, $a$ 代表常数项, $G$ 代表人均 $\mathrm{GDP}, b_{1} 、 b_{2} 、 b_{3}$ 表示的一次项、二次项和三次 项系数, $\varepsilon$ 代表随机干扰项。

\section{4 数据检验}

为避免出现 “伪回归” 问题, EKC 曲线拟合前需对数据进行协整检验, 以判断非稳定序列的线性组合是否 
具有协整关系,也可以判断线性回归方程的合理性。检验结果若序列是平稳的,则回归方程设定合理,说明回 归方程的因变量和解释变量之间存在稳定的均衡关系。

各变量的平稳性检验是协整检验的第一步。本文采用 EViews 软件中的增广迪基-福勒 (ADF, Augmented Dickey-Fuller) 单位根检验判断各变量序列的平稳性。若各检验变量具备相同的单整阶数, 则序列平稳。ADF 是以“存在单位根,变量是非平稳序列”为原假设的左侧单侧检验。根据赤池信息量 (AIC, Akaike information criterion) 准则确定最佳滞后期。对 31 个省份、京津冀及周边地区、长三角地区和珠三角地区 ( 以下简称三大 重点区域) $2001-2019$ 年 $\mathrm{SO}_{2} 、 \mathrm{PM}_{10} 、 \mathrm{NO}_{2}$ 浓度与人均 GDP 指标数值进行 $\mathrm{ADF}$ 平稳性检验, 在 $5 \%$ 显著水平下, 31 个省份和三大重点区域二阶差分后,各变量序列均拒绝原假设,呈平稳序列 (表 2)。

表 2 ADF 单位根检验结果

Table 2 ADF unit root test results

\begin{tabular}{|c|c|c|c|c|c|}
\hline $\begin{array}{l}\text { 地区 } \\
\text { Region }\end{array}$ & $\begin{array}{l}\text { 变量 } \\
\text { Variable }\end{array}$ & $\begin{array}{l}\text { 检验形式 } \\
\text { Test form }\end{array}$ & $\begin{array}{c}\text { ADF 检验值 } \\
\text { ADF test value }\end{array}$ & $\begin{array}{c}5 \% \text { 显著水平 } \\
5 \% \text { Significance } \\
\text { level }\end{array}$ & $\begin{array}{c}\text { 判断结果 } \\
\text { Results }\end{array}$ \\
\hline \multirow{4}{*}{31 个省份 China's 31 provinces } & $\operatorname{lnGDP}$ & $(0,0,0)$ & -4.55 & -1.96 & 平稳 \\
\hline & $\operatorname{lnSO}_{2}$ & $(0,0,1)$ & -5.19 & -1.97 & 平稳 \\
\hline & $\operatorname{lnPM}_{10}$ & $(0,0,1)$ & -4.22 & -1.97 & 平稳 \\
\hline & $\operatorname{lnNO}_{2}$ & $(0,0,1)$ & -7.97 & -1.97 & 平稳 \\
\hline 京津冀及周边地区 & $\operatorname{lnGDP}$ & $(\mathrm{C}, \mathrm{T}, 0)$ & -4.19 & -3.73 & 平稳 \\
\hline The Beijing-Tianjin-Hebei and & $\operatorname{lnSO}_{2}$ & $(0,0,0)$ & -5.11 & -1.96 & 平稳 \\
\hline \multirow[t]{2}{*}{ its surrounding areas } & $\operatorname{lnPM}_{10}$ & $(0,0,0)$ & -6.67 & -1.96 & 平稳 \\
\hline & $\operatorname{lnNO}{ }_{2}$ & $(0,0,1)$ & -5.19 & -1.97 & 平稳 \\
\hline 长三角地区 & $\operatorname{lnGDP}$ & $(0,0,0)$ & -3.77 & -1.96 & 平稳 \\
\hline \multirow[t]{3}{*}{ The Yangtze River Delta region } & $\operatorname{lnSO}_{2}$ & $(0,0,1)$ & -4.37 & -1.97 & 平稳 \\
\hline & $\operatorname{lnPM}_{10}$ & $(0,0,1)$ & -4.77 & -1.97 & 平稳 \\
\hline & $\operatorname{lnNO_{2}}$ & $(0,0,0)$ & -5.83 & -1.96 & 平稳 \\
\hline 珠三角地区 & $\operatorname{lnGDP}$ & $(0,0,0)$ & -4.55 & -1.96 & 平稳 \\
\hline \multirow[t]{3}{*}{ The Pearl River Delta region } & $\operatorname{lnSO} O_{2}$ & $(0,0,1)$ & -5.19 & -1.97 & 平稳 \\
\hline & $\operatorname{lnPM}_{10}$ & $(0,0,1)$ & -8.23 & -1.97 & 平稳 \\
\hline & $\operatorname{lnNO}_{2}$ & $(0,0,1)$ & -9.23 & -1.97 & 平稳 \\
\hline
\end{tabular}

ADF : 增广迪基-福勒 Augmented Dickey-Fuller

由于污染物浓度变量有 3 个, Johansen 检验是进行多变量 I $(2)$ 序列协整检验的较好方法。检验结果显 示, 在 $5 \%$ 显著水平下, 31 个省份特征根迹检验证明 4 个变量之间存在至少 3 个长期的稳定关系, 三大重点区 域均存在至少一个长期的稳定关系, 即污染物浓度指标与经济变量之间存在协整关系, 可继续进行实证分析 (表 3)。

\section{2 结果分析}

\section{1 经济增长概况}

2000-2019 年, 31 个省份人均 GDP 从 0.8 万元增加到 4.7 万元, 年均增长 $9.8 \%$ 。从每年的增长率看, 2002-2011 年增长率达两位数以上,但自 2012 年增长率首次降至 10\%以下后,增速逐年放缓,2019 年同比增 长 $5.8 \%$, 为历年最低值。三大重点区域总体也维持在高速增长, 人均 GDP 年增速维持在 $4.6 \%$ 以上。人均 GDP 增速变化趋势与 31 个省份大致相同,2001-2007 年处于高速增长期, 人均 GDP 增速最高达到 $14.3 \%$,出 现在 2005 年的京津冀及周边地区。2008-2012 年增速明显放缓, 人均 GDP 增速最低为 $7.3 \%$,出现在 2012 年的珠三角地区。2013-2019 年,三大重点区域经济增速降幅趋缓, 均在 2 个百分点范围内波动。2019 年京 津冀及周边地区、长三角地区、珠三角地区人均 GDP 增速分别为 5.7\%、5.6\%、4.6\% ,均为历年最低值(图 2)。 
表 3 Johansen 特征根迹检验结果

Table 3 Johansen characteristic root trace test results

\begin{tabular}{|c|c|c|c|c|c|}
\hline $\begin{array}{l}\text { 地区 } \\
\text { Region }\end{array}$ & $\begin{array}{c}\text { 原假设 } \\
\text { Null hypothesis }\end{array}$ & $\begin{array}{c}\text { 特征值 } \\
\text { Characteristic value }\end{array}$ & $\begin{array}{c}\text { 迹统计量 } \\
\text { Trace statistic }\end{array}$ & $\begin{array}{c}5 \% \text { 临界值 } \\
5 \% \text { Critical value }\end{array}$ & $P$ \\
\hline \multirow[t]{4}{*}{31 个省份 China's 31 provinces } & None * & 0.843491 & 74.95640 & 47.85613 & 0.0000 \\
\hline & At most $1 *$ & 0.804024 & 43.42750 & 29.79707 & 0.0008 \\
\hline & At most $2^{*}$ & 0.602527 & 15.72149 & 15.49471 & 0.0462 \\
\hline & At most 3 & 0.002162 & 0.036798 & 3.841466 & 0.8478 \\
\hline 京津冀及周边地区 & None * & 0.93476 & 69.5768 & 47.8561 & 0.0001 \\
\hline The Beijing-Tianjin-Hebei and & At most 1 & 0.52793 & 20.4423 & 29.7971 & 0.3933 \\
\hline \multirow[t]{2}{*}{ its surrounding areas } & At most 2 & 0.30878 & 6.93109 & 15.4947 & 0.5857 \\
\hline & At most 3 & 0.01563 & 0.28362 & 3.84147 & 0.5943 \\
\hline 长三角地区 & None * & 0.91281 & 61.4739 & 47.8561 & 0.0016 \\
\hline \multirow[t]{3}{*}{ The Yangtze River Delta region } & At most 1 & 0.44017 & 17.56 & 29.7971 & 0.5986 \\
\hline & At most 2 & 0.32638 & 7.11792 & 15.4947 & 0.564 \\
\hline & At most 3 & 0.00036 & 0.00644 & 3.84147 & 0.9355 \\
\hline 珠三角地区 & None * & 0.90594 & 68.8322 & 47.8561 & 0.0002 \\
\hline \multirow[t]{3}{*}{ The Pearl River Delta region } & At most 1 & 0.58125 & 26.2830 & 29.7971 & 0.1204 \\
\hline & At most 2 & 0.44006 & 10.6144 & 15.4947 & 0.2364 \\
\hline & At most 3 & 0.00972 & 0.17586 & 3.84147 & 0.675 \\
\hline
\end{tabular}

* 表示在 $5 \%$ 的显著性水平下拒绝原假设

$2.2 \mathrm{SO}_{2}$ 浓度与经济增长 $\mathrm{EKC}$ 曲线分析

\subsection{1 $\mathrm{SO}_{2}$ 浓度演变}

2000-2019 年,我国 31 个省份 $\mathrm{SO}_{2}$ 浓度整体呈现大幅下降的趋势, 2019 年比 2000 年下降 $76 \%$; 同比下降 的年份有 16 年。 31 个省份 $\mathrm{SO}_{2}$ 浓度 2001-2003 年仍处于缓慢上升状态, 2003 年同比增幅 (以下简称增幅) 高达 14\%;2004-2012 年,保持稳定下降趋势,2012 年降幅最大为 9\%;2014-2019 年, 降幅较往年明显增大, 其中 2018 年降幅为历年最大的 $22 \%$ 。从重点区域看 (图 3), 京津冀及周边地区、长三角地区、珠三角地区 $\mathrm{SO}_{2}$ 浓度也是大幅下降, 2019 年比 2000 年依次下降 $80 \% 、 64 \% 、 54 \%$ 。三大重点区域分别于 2004 年、2006 年 和 2005 年首次同比下降,且在此之后处于稳定下降状态。除长三角地区和珠三角地区分别于 2007 和 2006 年出现短暂反弹外,其余年度均同比下降。其中,2014-2017 年降幅明显较往年增大;2018-2019 年,京津冀 及周边地区和长三角地区继续大幅下降,其中 2018 年分别为历年最低的 $31 \%$ 和 $24 \%$, 珠三角地区降幅有所 收窄。

\subsubsection{EKC 曲线分析}

根据公式(3) 在 SPSS 软件中回归分析得 31 个省份、京津冀及周边地区、长三角地区、珠三角地区 $\mathrm{SO}_{2}$ 浓 度和人均 GDP 方程分别见公式(4)-(7), 得到拟合曲线如图 4, $R^{2}$ 均大于 0.8 , 拟合效果优良, 均呈现典型倒 U 型曲线关系,计算其曲线拐点 (最高点) 对应的人均 $\mathrm{GDP}$ 和 $\mathrm{SO}_{2}$ 年均浓度, 31 个省份、京津冀及周边地区、长三 角地区、珠三角地区分别为 1.3 万元和 $48 \mu \mathrm{g} / \mathrm{m}^{3} 、 1.0$ 万元和 $80 \mu \mathrm{g} / \mathrm{m}^{3} 、 2.4$ 万元和 $39 \mu \mathrm{g} / \mathrm{m}^{3} 、 2.2$ 万元和 $29 \mu \mathrm{g} /$ $\mathrm{m}^{3}$, 对应的时间分别介于 2004-2005 年、2002-2003 年、2006-2007 年、2005-2006 年之间, 表明分别于 2004 年、2002 年、2006 年、2005 年前后越过拐点,随着人均 GDP 逐年增长, $\mathrm{SO}_{2}$ 浓度实现同步下降, 污染大幅 减轻。

$$
\begin{array}{ll}
\operatorname{lnSO}_{2}=-68.868+15.323 \ln G D P-0.807(\operatorname{lnGDP})^{2} & R^{2}=0.939 \\
\operatorname{lnSO}_{2}=-47.088+11.123 \ln \mathrm{l} D-0.601(\operatorname{lnGDP})^{2} & R^{2}=0.861 \\
\operatorname{lnSO}_{2}=-127.609+26.076 \ln G D P-1.295(\operatorname{lnGDP})^{2} & R^{2}=0.948 \\
\operatorname{lnSO}_{2}=-114.467+23.552 \ln \mathrm{l} D P-1.177(\operatorname{lnGDP})^{2} & R^{2}=0.974
\end{array}
$$


$2.3 \mathrm{PM}_{10}$ 浓度与经济增长 $\mathrm{EKC}$ 曲线分析

\subsection{1 $\mathrm{PM}_{10}$ 浓度演变}

$2001-2019$ 年,我国 31 个省份 $\mathrm{PM}_{10}$ 年均浓度总体 呈现稳步下降趋势, 年度同比变幅变化趋势如图 5 所 示。从 31 个省份看, 2019 年 $\mathrm{PM}_{10}$ 浓度比 2001 年下降 $44 \%$;同比下降的年份有 15 年。从年际变化看, 20032005 年显著下降,其中 2005 年降幅达 $12 \%$;2015 年降 幅同比大幅增加,达到 $11 \%$ 。从重点区域看,2019 年比 2001 年依次下降 34\%、47\%、28\%。2002-2012 年, 虽 然个别年份出现同比反弹,如 2012 年的京津冀及周边 地区、2010 年的长三角地区、2007 年的珠三角地区,但 总体仍呈稳步下降趋势; 2014-2016 年, 均大幅下降, 且降幅较往年略有增大;2018一-2019 年出现分化,京津 冀及周边地区和长三角地区保持下降趋势,珠三角地区 则先降后升。

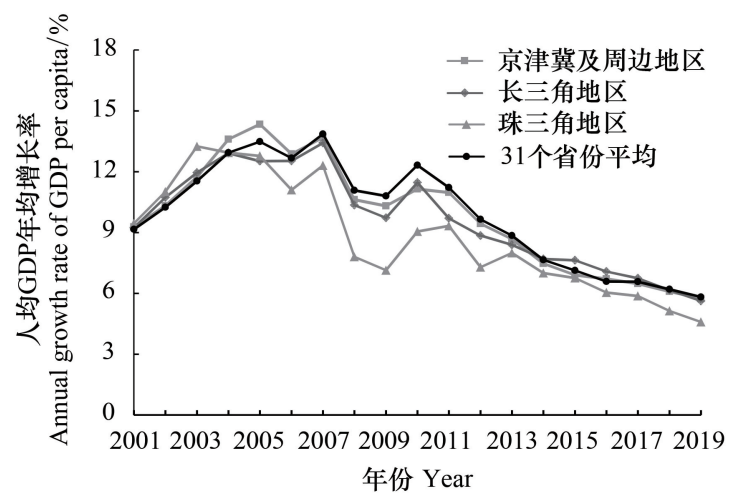

图 2 我国重点区域 2001一2019 年人均 GDP 增长率变化趋势

Fig.2 Trend of GDP per capita growth rate of key regions in China, 2001-2019

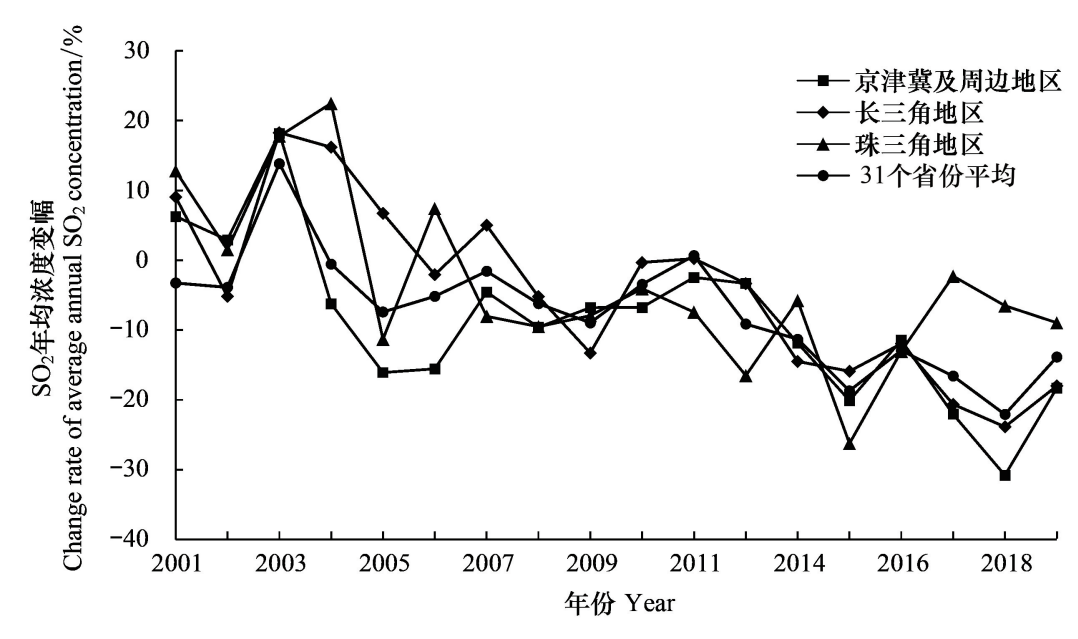

图 3 我国重点区域 $2001-2019$ 年 $\mathrm{SO}_{2}$ 年均浓度变幅变化趋势

Fig.3 Trend of average annual $\mathrm{SO}_{2}$ concentration in key regions of China, 2001-2019

\subsubsection{EKC 曲线分析}

根据公式(3) 在 SPSS 软件中回归分析得到 2001-2019 年 31 个省份、京津冀及周边地区、长三角地区、珠 三角地区 $\mathrm{PM}_{10}$ 浓度和人均 GDP 的回归方程和拟合曲线(图 6), 曲线类型均有所不同。

(1) 31 个省份

$\mathrm{PM}_{10}$ 浓度与人均 GDP 的回归方程见公式 $(8), R^{2}$ 为 0.878 , 拟合效果良好, 呈现倒 $\mathrm{N}$ 型曲线关系。2001一 2008 年 EKC 曲线先呈现出逐步下降趋势, 但下降趋势逐渐平缓; 2009 年前后出现第 1 个拐点, 对应人均 GDP 为 2.1 万元 $/$ 人, $\mathrm{PM}_{10}$ 年均浓度为 $78 \mu \mathrm{g} / \mathrm{m}^{3} ; 2010-2012$ 年,曲线呈轻微上升趋势; 2013 年前后出现第 2 个拐 点, 对应人均 GDP 为 3.2 万元 $/$ 人, $\mathrm{PM}_{10}$ 年均浓度为 $88 \mu \mathrm{g} / \mathrm{m}^{3} ; 2014-2019$ 年曲线再次呈现出下降趋势, 随着 经济增长 $\mathrm{PM}_{10}$ 浓度实现同步下降, 污染逐步减轻。

$$
\operatorname{lnPM}_{10}=287-84.24 \ln G D P+8.4(\operatorname{lnGDP})^{2}-0.28(\operatorname{lnGDP})^{3} \quad R^{2}=0.878
$$

(2) 京津冀及周边地区

$\mathrm{PM}_{10}$ 年均浓度与人均 GDP 的回归方程见公式 $(9), R^{2}$ 为 0.474 , 拟合效果一般,呈现出 U 型曲线关系。随 

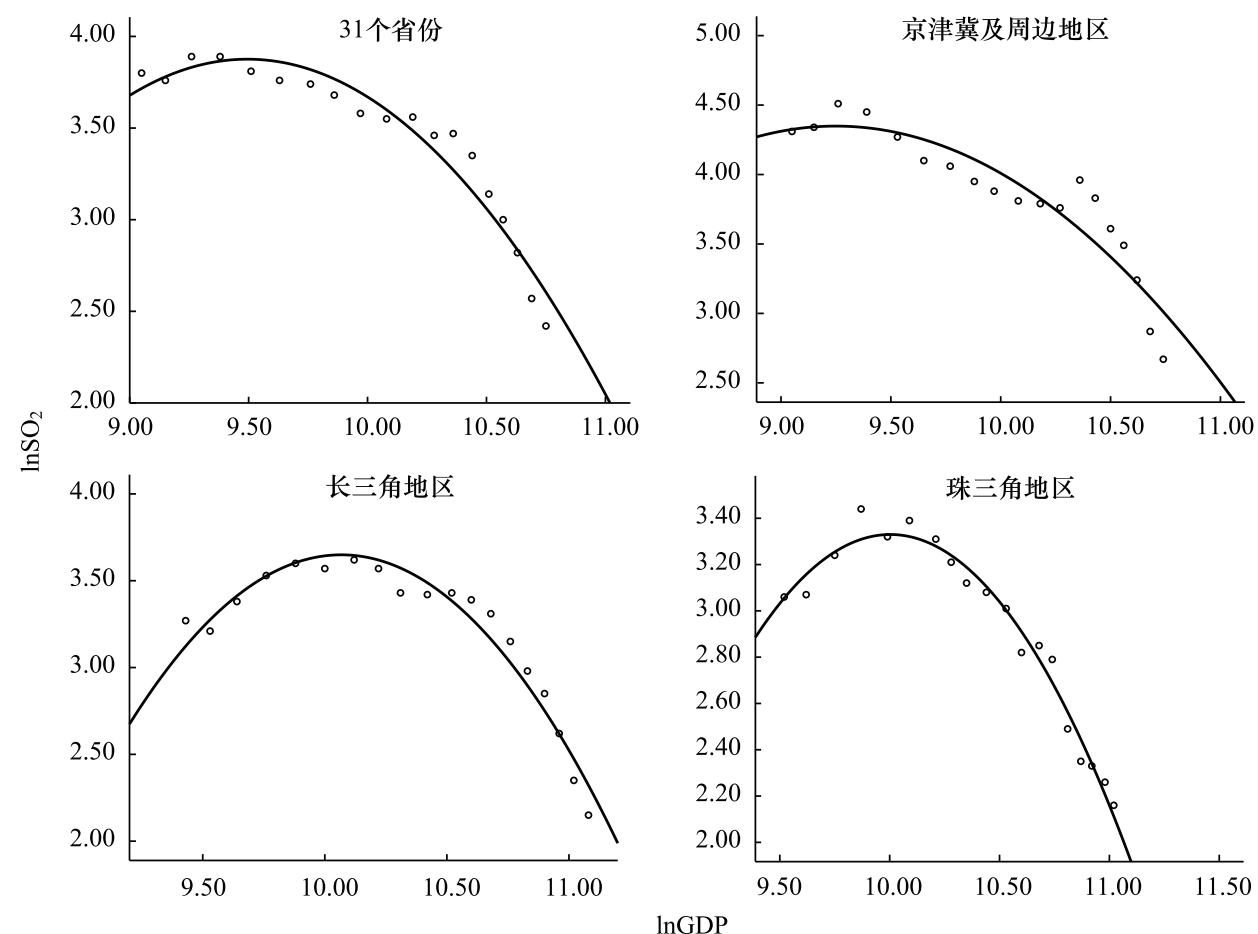

图 $42001-2019$ 年 $\mathrm{SO}_{2}$ 浓度与人均 GDP 拟合曲线

Fig.4 The fitting curve of $\mathrm{SO}_{2}$ concentration and GDP per capita, 2001-2019

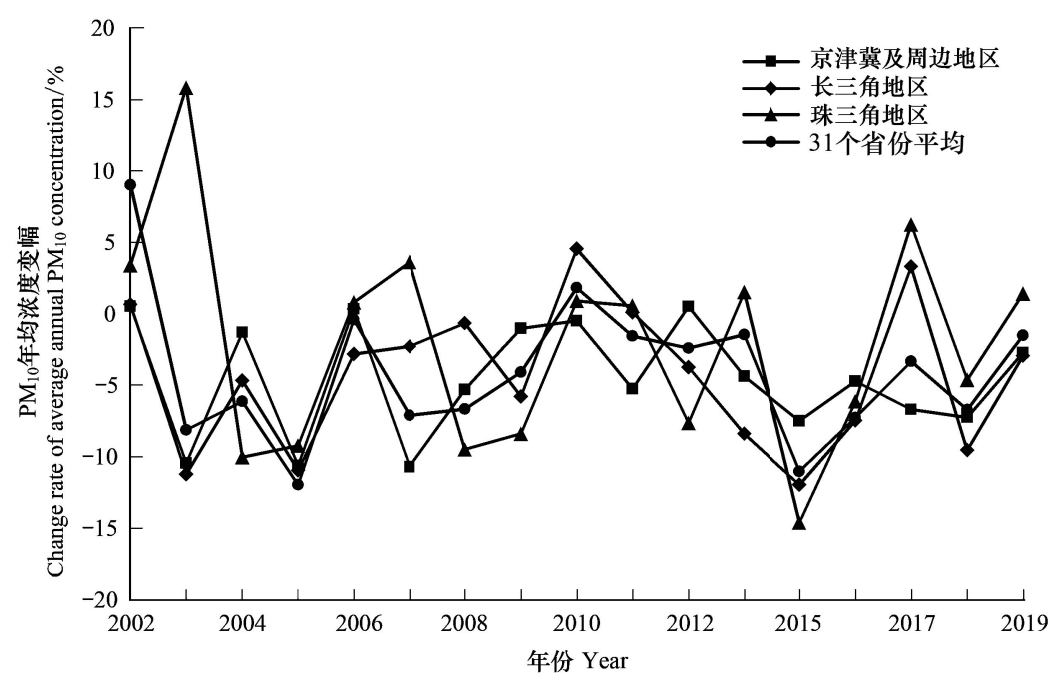

图 5 我国重点区域 2002-2019 年 $\mathrm{PM}_{10}$ 年均浓度变幅变化趋势

Fig.5 Trend of average annual $\mathrm{PM}_{10}$ concentration in key regions of China, 2001-2019

着经济增长, 2001-2010 年京津冀及周边地区 $\mathrm{PM}_{10}$ 浓度明显下降, 于 2012 年越过最低点 (对应人均 GDP 为 2.6 万元 $/$ 人, $\mathrm{PM}_{10}$ 浓度为 $98 \mu \mathrm{g} / \mathrm{m}^{3}$ ) 后, 浓度逐渐上升, 污染呈反弹趋势。若不强化 $\mathrm{PM}_{10}$ 污染管控, 随着经济 稳定增长, $\mathrm{PM}_{10}$ 浓度将按照拟合曲线所示持续抬升。

$$
\operatorname{lnPM}_{10}=34.413-5.862 \operatorname{lnGDP}+0.288(\operatorname{lnGDP})^{2} \quad R^{2}=0.474
$$

(3) 长三角地区

$\mathrm{PM}_{10}$ 年均浓度与人均 GDP 的回归方程见公式 $(10), R^{2}$ 为 0.817 , 拟合效果良好, 呈现 $U$ 型曲线关系。目 
前曲线仍处于 $\mathrm{U}$ 型左侧的下降阶段, 尚未达到拐点。但鉴于三次项系数 $b_{3}$ 小于 0.05 , 曲线更接近于二次单调 下降的曲线。表明 2001-2019 年经济稳定增长的同时, $\mathrm{PM}_{10}$ 浓度实现同步下降,污染逐渐减轻。

$$
\operatorname{lnPM}_{10}=12.465-1.252 \operatorname{lnGDP}+0.046(\operatorname{lnGDP})^{2} \quad R^{2}=0.817
$$

(4) 珠三角地区

$\mathrm{PM}_{10}$ 年均浓度与人均 GDP 的回归方程见公式 $(11), R^{2}$ 为 0.857 , 拟合效果良好, 呈现出倒 $\mathrm{U}$ 型曲线关系。 目前曲线已于 2001 年前越过拐点,处于右侧下降阶段。表明在 2001-2019 年间经济稳定增长的同时 $\mathrm{PM}_{10}$ 浓 度实现同步下降, 污染逐渐减轻。

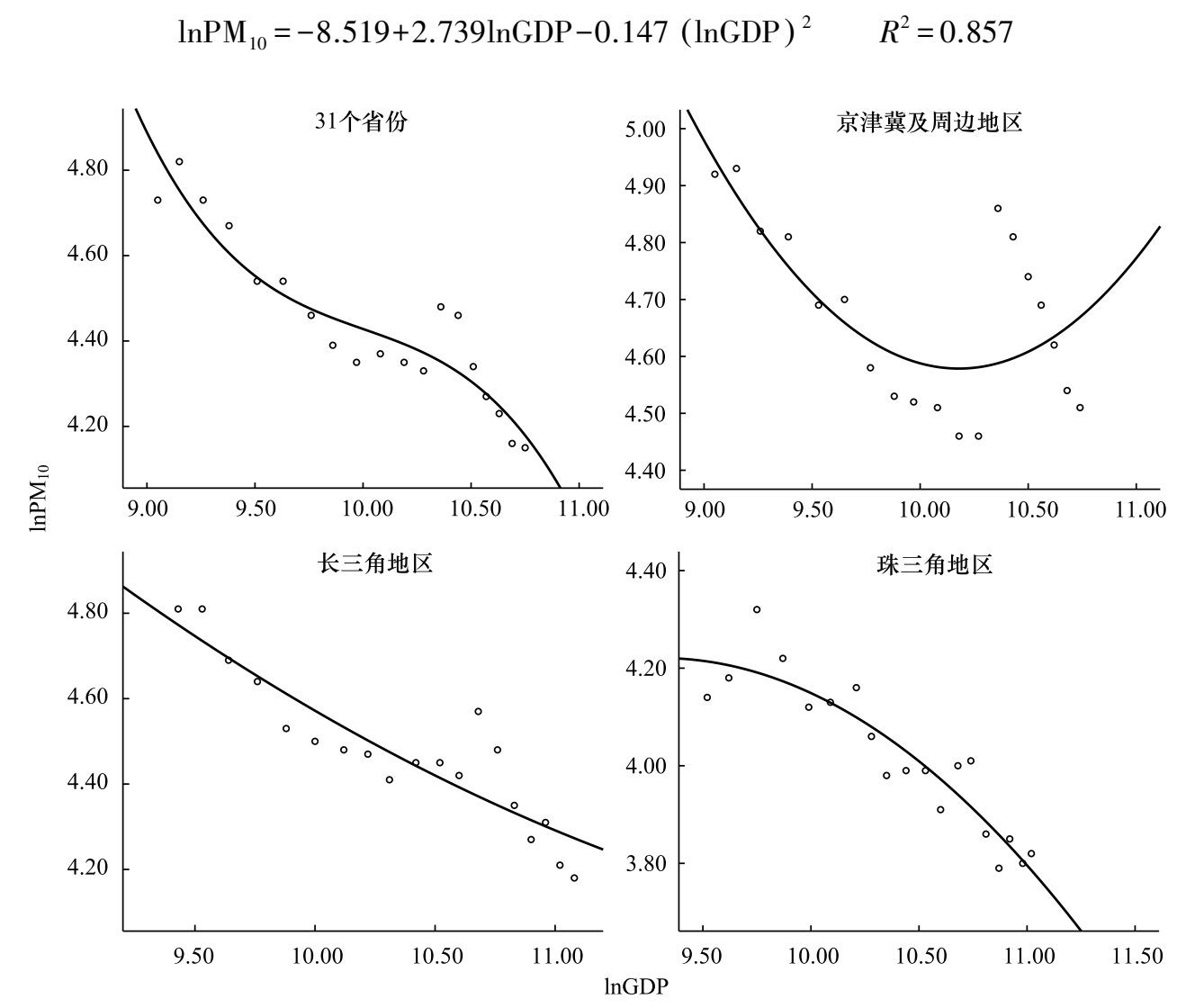

图 $62001-2019$ 年 $\mathrm{PM}_{10}$ 浓度与人均 GDP 拟合曲线

Fig.6 The fitting curve of $\mathrm{PM}_{10}$ concentration and GDP per capita, 2001-2019

$2.4 \mathrm{NO}_{2}$ 浓度与经济增长 $\mathrm{EKC}$ 曲线分析

\subsection{1 $\mathrm{NO}_{2}$ 浓度演变}

2001-2019 年,我国 31 个省份 $\mathrm{NO}_{2}$ 浓度整体呈现波动缓慢下降的趋势,年度同比变幅变化趋势如图 7 所 示。31 个省份 2019 年 $\mathrm{NO}_{2}$ 浓度比 2001 年仅下降 $9.2 \%$; 同比下降的年份有 11 年。从年际变化看, 20022012 年末呈现明显变化趋势, 变幅均在 4\%以内; 2014-2019 年, 变幅较往年略有增大, 其中 2015 年和 2018 年降幅均为 $6 \%$,为历年最大值。三大重点区域 $\mathrm{NO}_{2}$ 浓度整体未有明显变化趋势, 2019 年比 2001 年分别仅依 次下降 5\%、1\%、6\%。京津冀及周边地区呈现窄幅波动,降幅最大的两个年份是 2005 和 2006 年(均为-7\%); 长三角地区波动幅度较大, 降幅最大的两个年份是 2002 年 $(-7 \%)$ 和 2018 年 $(-6 \%)$, 反弹幅度最大是 2010 年 $(11 \%)$, 变幅波动高达 17 个百分点; 珠三角地区波动幅度与长三角地区相当, 降幅最大的两个年份是 2015 年 $(-9 \%)$ 和 2005 年 $(-8 \%)$, 反弹幅度最大的两个年份是 2003 年 $(16 \%)$ 和 2017 年 $(7 \%)$ 。由此可见,三大重 点区域 $\mathrm{NO}_{2}$ 浓度未呈现任何规律性变化, 且彼此间趋势差异较大。 


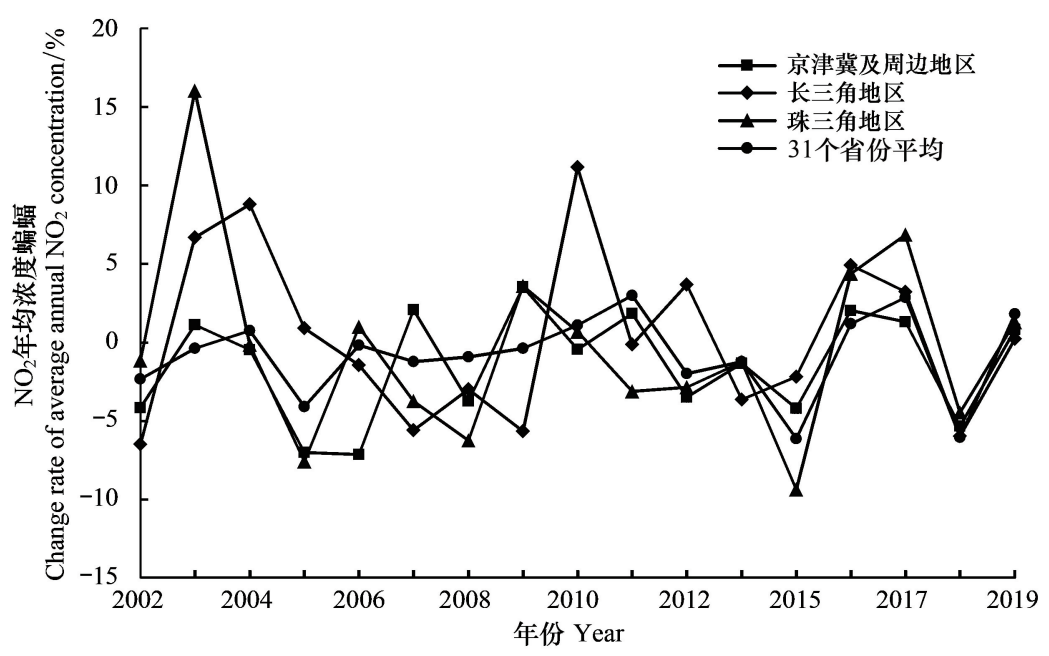

图 7 我国重点区域 2002-2019 年 $\mathrm{NO}_{2}$ 年均浓度变幅变化趋势

Fig.7 Trend of average annual $\mathrm{NO}_{2}$ concentration in key regions of China, 2001-2019

\subsubsection{EKC 曲线分析}

根据公式(3) 在 SPSS 软件中回归分析得到 31 个省份、京津冀及周边地区、长三角地区、珠三角地区 $\mathrm{NO}_{2}$ 浓度和人均 GDP 的回归方程和拟合曲线(图 8)。

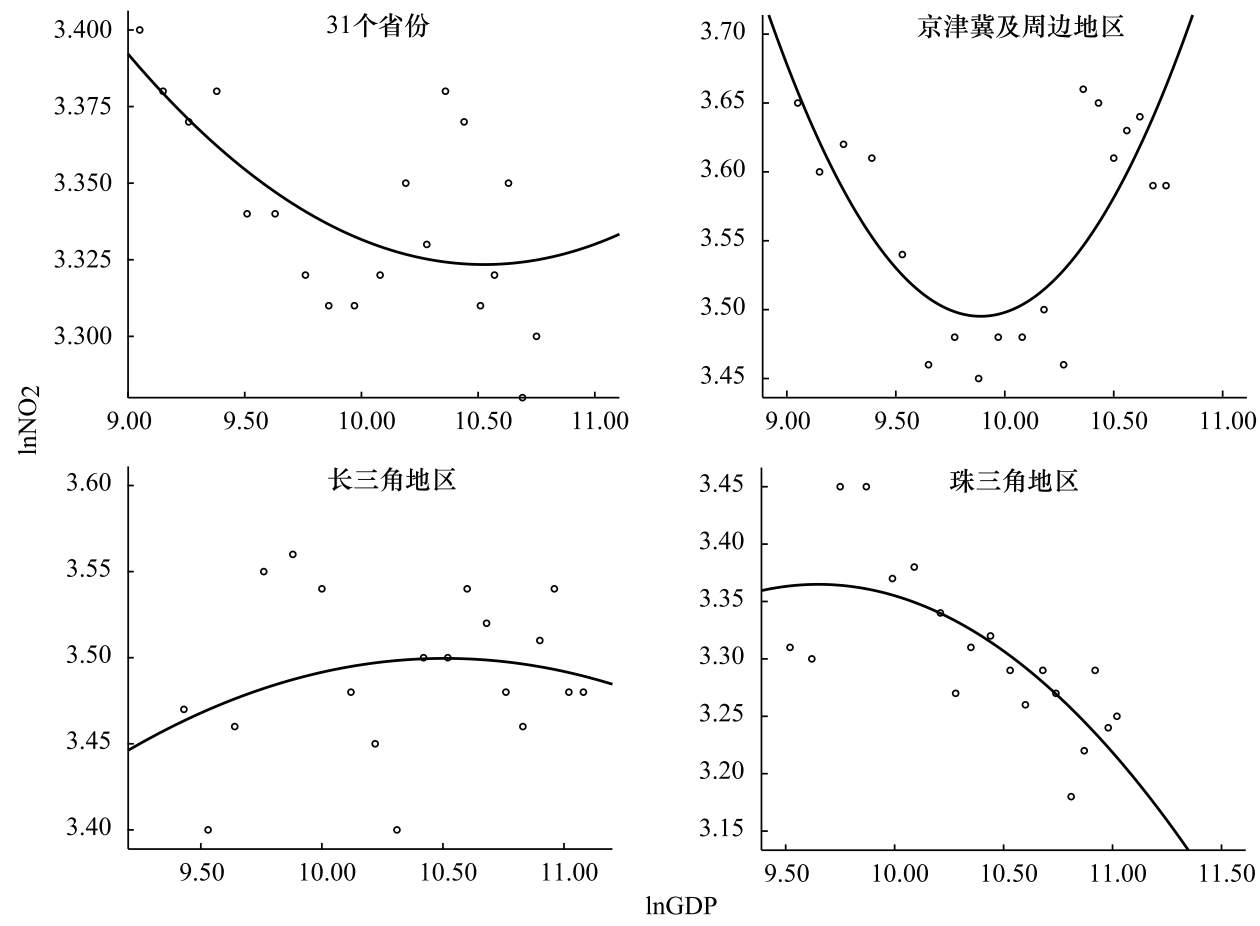

图 $82001-2019$ 年 $\mathrm{NO}_{2}$ 浓度与人均 GDP 拟合曲线

Fig.8 The fitting curve of $\mathrm{NO}_{2}$ concentration and GDP per capita, 2001-2019

(1) 31 个省份

$\mathrm{NO}_{2}$ 浓度与人均 GDP 的回归方程见公式 $(12), R^{2}$ 为 0.402 , 拟合效果一般,呈 $U$ 型曲线关系。通过计算可 得, 曲线拐点 (最低点) 对应的人均 GDP 为 3.1 万元, $\mathrm{NO}_{2}$ 年均浓度为 $29 \mu \mathrm{g} / \mathrm{m}^{3}$, 介于 $2012-2013$ 年之间。 
2013 年后, 曲线呈缓慢上升趋势。表明随着经济增长, 2001-2012 年,31 个省份 $\mathrm{NO}_{2}$ 污染逐渐减轻; 2013 年 后, $\mathrm{NO}_{2}$ 污染呈缓慢反弹态势。

$$
\operatorname{lnNO}_{2}=6.593-0.621 \operatorname{lnGDP}+0.030(\operatorname{lnGDP})^{2} \quad R^{2}=0.402
$$

(2) 京津冀及周边地区

$\mathrm{NO}_{2}$ 年均浓度与人均 $\mathrm{GDP}$ 的回归方程见公式 (13), $R^{2}$ 为 0.559 , 拟合效果一般,呈现 U 型曲线关系。随着 经济增长, 2001-2008 年京津冀及周边地区 $\mathrm{NO}_{2}$ 污染呈明显下降趋势, 于 2009 年越过最低点 (对应人均 GDP 约为 2.0 万元 $/$ 人, $\mathrm{NO}_{2}$ 年均浓度约为 $32 \mu \mathrm{g} / \mathrm{m}^{3}$ ) 后, $2009-2019$ 年污染呈明显反弹趋势。

$$
\operatorname{lnNO}_{2}=26.106-4.573 \ln G D P+0.231(\operatorname{lnGDP})^{2} \quad R^{2}=0.559
$$

(3) 长三角地区

$\mathrm{NO}_{2}$ 年均浓度与人均 GDP 的回归方程见公式 (14), 但该方程在 $5 \%$ 的显著性水平下未能通过检验, $R^{2}$ 仅 为 0.053 , 表明 $\mathrm{NO}_{2}$ 年均浓度与人均 GDP 之间并无相关关系。

(4) 珠三角地区

$$
\operatorname{lnNO}_{2}=0.049+0.657 \operatorname{lnGDP}-0.031(\operatorname{lnGDP})^{2} \quad R^{2}=0.053
$$

$\mathrm{NO}_{2}$ 年均浓度与人均 GDP 的回归方程见公式 $(15), R^{2}$ 为 0.547 , 拟合效果一般, 呈现倒 $\mathrm{U}$ 型曲线。目前曲 线已经越过 2002-2003 年间的拐点 (对应人均 GDP 约为 1.6 万元 $/$ 人, $\mathrm{NO}_{2}$ 浓度为 $30 \mu \mathrm{g} / \mathrm{m}^{3}$ ), 处于右侧下降 阶段。表明 2003-2019 年珠三角地区经济增长的同时 $\mathrm{NO}_{2}$ 污染逐渐减轻。

$$
\operatorname{lnNO}_{2}=-4.108+1.549 \operatorname{lnGDP}-0.080(\operatorname{lnGDP})^{2} \quad R^{2}=0.547
$$

\section{3 讨论和政策建议}

\section{1 我国环境空气质量与经济增长 $\mathrm{EKC}$ 曲线分析}

2001-2019 年我国 31 个省份 $\mathrm{SO}_{2} 、 \mathrm{PM}_{10}$ 和 $\mathrm{NO}_{2}$ 浓度与经济增长分别呈倒 $\mathrm{U}$ 型、倒 $\mathrm{N}$ 型和 $\mathrm{U}$ 型曲线, 并均 已越过拐点。即随着经济增长, $\mathrm{SO}_{2}$ 和 $\mathrm{PM}_{10}$ 浓度逐渐降低, 而 $\mathrm{NO}_{2}$ 浓度逐渐上升。究其原因, 从 $\mathrm{SO}_{2}$ 看, 我国超 过 $90 \%$ 的 $\mathrm{SO}_{2}$ 排放来自煤炭消费, 主要是在燃煤电厂和能源密集型产业 ${ }^{[45-46]}$ 。我国自 2000 年起颁布实施“十 五” 规划等政策措施, 将 $\mathrm{SO}_{2}$ 作为总量控制指标, 重点针对燃煤电厂采取管控措施大力削减 $\mathrm{SO}_{2}$ 排放, 使得 $\mathrm{SO}_{2}$ 排放总量于 2006 年达峰 ${ }^{[47]}$, 进而 $\mathrm{SO}_{2}$ 浓度实现稳步下降, 推动 $\mathrm{EKC}$ 曲线在 2005 年前后出现拐点。2013 年先 后颁布《大气十条》《三年行动计划》则通过燃煤电厂超低排放改造、加快淘汰落后产能、化解钢铁水泥等高能 耗高排放行业产能、淘汰燃煤小锅炉、民用散煤治理等措施进一步强化 $\mathrm{SO}_{2}$ 减排。评估显示, 我国 2017 年 $\mathrm{SO}_{2}$ 排放量比 2013 年减少 59\%, 主要是得益于淘汰和升级燃煤锅炉、燃煤电厂超低排放改造和淘汰落后产能,推 动 $\mathrm{SO}_{2}$ 浓度大幅下降 ${ }^{[48-49]}$ 。在经济持续增长的前提下, $\mathrm{EKC}$ 曲线越过拐点后呈明显快速下降趋势。

从 $\mathrm{PM}_{10}$ 看, $\mathrm{PM}_{10}$ 主要人为源是化石燃料、生物质燃烧 ${ }^{[50]}$ 。我国自 20 世纪 70 年代起针对烟粉尘污染开展 治理, 1996 年我国将 $\mathrm{PM}_{10}$ 作为常规监测污染物, 2001 年后通过设定烟尘和工业粉尘的排放总量控制目标、修 订燃煤电厂烟尘浓度排放限值等方式治理 $\mathrm{PM}_{10}$ 污染。经过长达二三十年的综合整治, $\mathrm{PM}_{10}$ 污染控制取得较 为明显的成效,2000-2009 年我国 $\mathrm{PM}_{10}$ 浓度呈明显下降 ${ }^{[47]}$, 推动 $\mathrm{EKC}$ 曲线呈大幅下降趋势。但 $\mathrm{PM}_{10}$ 浓度在 2010 年同比出现反弹, 随后的两年虽转为下降, 但降幅较往年有所收窄, 导致 2010-2012 年 EKC 曲线逐渐走 平, 并呈略微上升趋势;2013 年以来, 《大气十条》《三年行动计划》通过实施工业企业提标改造、民用散煤治 理等重点治污任务, 在实现 $\mathrm{SO}_{2}$ 减排的同时也推动了 $\mathrm{PM}_{10}$ 协同减排; 此外, 针对施工工地、道路、裸地和矿山等 易扬尘点位, 进一步强化扬尘综合治理。评估显示, 2013-2017 年我国 $\mathrm{PM}_{10}$ 排放量减少 36\%, 重点区域 $\mathrm{PM}_{10}$ 中硫酸盐、有机物和扬尘浓度出现下降,有力证明了近年来我国 $\mathrm{PM}_{10}$ 污染防治措施的成效 ${ }^{[48-49]}$ 。2013-2019 年 $\mathrm{PM}_{10}$ 浓度显著下降,使得 $\mathrm{EKC}$ 曲线自 2013 年起再度掉头向下,并保持下降趋势。

从 $\mathrm{NO}_{2}$ 看, 我国 $\mathrm{NO}_{2}$ 主要来自化石燃料、生物质高温燃烧、汽车尾气排放等人为源产生的 $\mathrm{NO}_{x}(\mathrm{NO}$ 和 
$\left.\mathrm{NO}_{2}\right)^{[51-53]}$ 。 $\mathrm{NO}_{x}$ 来源分布在涉及高温燃烧的多个行业中, 涉及生产生活各个方面, 导致 $\mathrm{NO}_{x}$ 减排难度增加且 成本更高 ${ }^{[1]}$ 。虽然我国在《国家环境保护 “十一五” 规划中》提出控制高架源的的 $\mathrm{NO}_{x}$ 排放, 但实际上管控效 果不佳, 1990-2010 年 $\mathrm{NO}_{x}$ 排放量增加了 3 倍 ${ }^{[54]}$ 。“十二五” 规划将 $\mathrm{NO}_{x}$ 排放总量纳人约束性指标管理 ${ }^{[55]}$, 2013 年以来, 《大气十条》《三年行动计划》通过实施燃煤电厂、钢铁等重点行业超低排放改造, 强化机动车尾 气管控,推广新能源车等方式大力推进 $\mathrm{NO}_{x}$ 减排, 取得一定成效 ${ }^{[56-57]}$ 。但以上措施实现的 $\mathrm{NO}_{x}$ 减排量被机动 车保有量增长带来的污染排放增量抵消了, 导致 $\mathrm{NO}_{2}$ 浓度下降幅度有限 ${ }^{[48]}$ 。中国工程院评估显示, 2020 年 $\mathrm{NO}_{x}$ 比 2015 年的降幅远小于 $\mathrm{SO}_{2}$ 和一次颗粒物, 减排幅度明显不足 ${ }^{[58]}$ 。因此, 近年来我国 $\mathrm{NO}_{2}$ 浓度整体降幅 有限, 呈现来回波动状态, 导致曲线拟合效果不如 $\mathrm{SO}_{2}$ 和 $\mathrm{PM}_{10}$ 。在经济保持高速增长的情况下, 2013 年以来 $\mathrm{EKC}$ 曲线呈上升趋势,如不采取措施严加管控, 根据 $\mathrm{EKC}$ 曲线分析结果, $\mathrm{NO}_{2}$ 浓度可能持续反弹。

综上所述, 我们认为, $\mathrm{NO}_{2}$ 污染已成为我国当前大气污染防治的突出问题, 应进一步加大机动车污染防治 力度,一方面深人推进 “公转铁”, 从根本上改变目前以公路货运为主的交通运输结构, 减少污染排放大的柴 油货车使用量; 另一方面大力推广新能源车, 同时加强在用车监管, 进一步提升机动车排放标准和油品标准, 强化尾气监管, 大力削减机动车 $\mathrm{NO}_{x}$ 排放, 推动 $\mathrm{NO}_{2}$ 浓度稳步下降。

\section{2 重点区域 $\mathrm{SO}_{2}$ 浓度与经济增长 $\mathrm{EKC}$ 曲线分析}

2001-2019 年京津冀及周边地区、长三角地区和珠三角地区 $\mathrm{SO}_{2}$ 浓度与人均 GDP 的 EKC 曲线均呈典型 的倒 U 型, 且均已越过拐点。随着经济增长, $\mathrm{SO}_{2}$ 污染先呈恶化趋势, 达到一定程度后, 转而持续大幅改善。 不同的是, 三大重点区域 EKC 曲线出现拐点时间有所不同, 京津冀及周边地区率先于 2002 年越过拐点, 随后 珠三角、长三角分别于 2005 年和 2006 年越过拐点。表明京津冀及周边地区 $\mathrm{SO}_{2}$ 污染与经济增长协调关系好 转明显早于珠三角和长三角地区。我们分别分析经济增速、污染程度和改善情况等三方面因素对 EKC 曲线 类型及其长期变化趋势的影响程度。从经济增速看, 2000-2019 年京津冀及周边地区、长三角地区、珠三角 地区人均 GDP 年均增速分别为 $9.8 \% 、 9.6 \% 、 8.8 \%$, 差距不大。从污染严重程度看, 目前三大重点区域 $\mathrm{SO}_{2}$ 污 染均维持在较低水平。2019 年, 各区域浓度已基本维持在 $10 \mu \mathrm{g} / \mathrm{m}^{3}$ 左右, 其中污染最严重的京津冀及周边地 区浓度也仅为 $14 \mu \mathrm{g} / \mathrm{m}^{3}$, 均达到 $\mathrm{SO}_{2}$ 浓度一级标准 $\left(20 \mu \mathrm{g} / \mathrm{m}^{3}\right)$, 且仅为标准限值 $70 \%$ 及以下。从污染改善情 况看, 2019 年京津冀及周边地区 $\mathrm{SO}_{2}$ 浓度较 2001 年的降幅最高。2 21 世纪初期, 京津冀及周边地区 $\mathrm{SO}_{2}$ 浓度维 持在较高水平, 超出 $\mathrm{SO}_{2}$ 二级标准近 50\%, 约为长三角和珠三角地区的 3-4 倍。因此, 在强化 $\mathrm{SO}_{2}$ 减排的初 期, 京津冀及周边地区 $\mathrm{SO}_{2}$ 浓度较其他地区下降速度更快, 幅度明显更大, 因而率先出现拐点。此外, 值得注 意的是,三大重点区域 $\mathrm{SO}_{2}$ 浓度首次同比下降,并随后稳定处于下降状态的年份分别为 2004 年、2006 年、2005 年, 这与 $\mathrm{EKC}$ 曲线拐点出现年份高度吻合。这说明, 污染物浓度逐年下降, 形成稳定下降趋势, 可以推动 $\mathrm{EKC}$ 曲线稳定下降,也就是实现了环境空气质量与经济增长的长期关系持续优化,这也符合量变产生质变的原理。 这也充分说明我国持续制定并实施大气污染防治政策的必要性。

3.3 重点区域 $\mathrm{PM}_{10}$ 浓度与经济增长 $\mathrm{EKC}$ 曲线分析

2001-2019 年京津冀及周边地区、长三角地区和珠三角地区 $\mathrm{PM}_{10}$ 浓度与人均 GDP 的 $\mathrm{EKC}$ 曲线分别呈 $\mathrm{U}$ 型, 单调下降和倒 $\mathrm{U}$ 型。虽然京津冀及周边地区 $\mathrm{PM}_{10}$ 年均浓度基本呈稳定下降趋势, 但从 $\mathrm{EKC}$ 曲线看, 2013 年后却呈现出随着经济增长而反弹的趋势, 我们分析主要原因可能有两点: 一是因监测数据统计口径变动导 致数据出现非正常波动, 京津冀及周边地区 2013 年后突然升高, 间接拉高了曲线; 二是京津冀及周边地区 2014-2016 年 $\mathrm{PM}_{10}$ 浓度降幅不如长三角地区和珠三角地区。此外, 2019 年京津冀及周边地区 $\mathrm{PM}_{10}$ 浓度 $91 \mu \mathrm{g} / \mathrm{m}^{3}$ 比二级标准 $\left(70 \mu \mathrm{g} / \mathrm{m}^{3}\right)$ 高 $30 \%$, 污染程度较重; 长三角地区 $\left(65 \mu \mathrm{g} / \mathrm{m}^{3}\right)$ 达到二级标准, 珠三角地区 $\left(46 \mu \mathrm{g} / \mathrm{m}^{3}\right)$ 已接近一级标准 $\left.\left(40 \mathrm{~g} / \mu^{3}\right)^{3}\right)$ 。但鉴于京津冀及周边地区 2019 年实际 $\mathrm{PM}_{10}$ 浓度 $91 \mu \mathrm{g} / \mathrm{m}^{3}$ 已明显低 于拐点浓度 $98 \mu \mathrm{g} / \mathrm{m}^{3}$, 且 2013 年以来随着我国大气污染防治力度逐渐加大, 京津冀及周边地区 $\mathrm{PM}_{10}$ 浓度呈 稳定下降趋势。因此, 若以更长时间尺度预判, 在维持经济稳定增长的情况下, $\mathrm{EKC}$ 曲线缓慢上升后, 将拐头 向下, 最终预计呈现与 31 个省份类似的倒 $\mathrm{N}$ 型。长三角地区和珠三角地区 $\mathrm{EKC}$ 曲线均呈下降趋势, 这与近 
年来我国实施各项大气污染防治政策推动烟粉尘减排, $\mathrm{PM}_{10}$ 浓度稳步下降密切相关。因此, 我们认为, 京津 冀及周边地区应借鉴 2013 年以来 $\mathrm{PM}_{10}$ 污染治理经验, 针对 $\mathrm{PM}_{10}$ 主要来源生活源、工业源和扬尘源加大治理 力度,一是持续推动北方地区冬季清洁取暖,加快推进“煤改气” “煤改电”, 减少居民散煤使用量; 二是深人开 展工业企业提标改造,实施钢铁、水泥等行业超低排放改造,进一步降低工业源颗粒物等污染物减排; 三是深 化扬尘污染综合整治,加强施工扬尘精细化管控,进一步强化道路、裸地、堆场等扬尘综合治理。

3.4 重点区域 $\mathrm{NO}_{2}$ 浓度与经济增长 $\mathrm{EKC}$ 曲线分析

2001-2019 年 $\mathrm{NO}_{2}$ 年均浓度与经济发展的相关性均一般, 其中长三角地区无相关关系, 京津冀及周边地 区和珠三角地区分别呈现 U 型和倒 U 型。自 2001 年以来,三大重点区域均未出现明显下降趋势, 2019 年较 2001 年浓度降幅均在 6\%以内, 总体呈较为无序的波动状态, 没有呈现任何趋势性的规律, 导致其未能与稳定 增长的人均 GDP 形成较为显著的相关关系, 特别是长三角地区。从存在一定相关关系的区域对比看, 与 $\mathrm{PM}_{10}$ 浓度类似, 京津冀及周边地区受 2013 年监测数据统计口径变动导致数据出现非正常波动, 叠加近年来 $\mathrm{NO}_{2}$ 浓度未明显下降, 导致 $\mathrm{EKC}$ 曲线出现一定程度上升。但与 $\mathrm{PM}_{10}$ 不同的是, 拟合 $\mathrm{EKC}$ 拐点最低点对应的 浓度 $30 \mu \mathrm{g} / \mathrm{m}^{3}$, 明显低于 2019 年年均浓度 $36 \mu \mathrm{g} / \mathrm{m}^{3}$, 说明实际情况与拟合曲线基本一致, 呈污染反弹态势。 若不强化 $\mathrm{NO}_{2}$ 污染管控, 随着区域经济维持稳定增长, $\mathrm{NO}_{2}$ 浓度将持续抬升。珠三角地区 $\mathrm{NO}_{2}$ 浓度则稳定小幅 下降, 带动 $\mathrm{EKC}$ 曲线持续下降。相较于 $\mathrm{SO}_{2}$ 和 $\mathrm{PM}_{10}$, 三大区域的 $\mathrm{NO}_{2}$ 浓度与人均 GDP 长期关系的协调性均 较差, 因此, 需着力强化 $\mathrm{NO}_{x}$ 污染管控, 推动 $\mathrm{NO}_{2}$ 浓度稳步下降。

\section{4 结论}

本文运用 EKC 曲线模型通过对 2001-2009 年我国 31 个省份及重点区域大气污染物浓度和人均 GDP 进 行相关性检验, 分析得出二者之间相关及变化趋势。整体来看, 我国大气治理成效显著,近年来实施的各项大 气污染防治政策,特别是 2013 年以来颁布实施的《大气十条》《三年行动计划》,推动环境空气质量改善的同 时,促进了经济发展与环境保护长期关系协调性逐步增强。31 个省份和三大重点区域 $\mathrm{SO}_{2} 、 \mathrm{PM}_{10} 、 \mathrm{NO}_{2}$ 浓度与 经济增长的 $\mathrm{EKC}$ 曲线类型有所不同, $\mathrm{SO}_{2}$ 浓度与人均 $\mathrm{GDP}$ 变化相关性最强, $\mathrm{PM}_{10}$ 次之, $\mathrm{NO}_{2}$ 相关性一般。总体 来看, 31 个省份和三大重点区域的 $\mathrm{SO}_{2}$ 浓度与经济增长均处在典型倒 $\mathrm{U}$ 型关系的下降阶段。31 个省份、长三 角地区、珠三角地区 $\mathrm{PM}_{10}$ 浓度与经济增长分别呈现倒 $\mathrm{N}$ 型、 $\mathrm{U}$ 型和倒 $\mathrm{U}$ 型, 并均处于下降阶段, 其中长三角地 区更接近于单调下降, 京津冀及周边地区则受改善幅度不足等因素影响, 导致呈 $\mathrm{U}$ 型关系, 并已越过拐点处 于上升阶段。受近年来 $\mathrm{NO}_{2}$ 污染改善程度不明显等因素影响, $\mathrm{NO}_{2}$ 浓度与经济增长相关性最低, 其中长三角 地区无相关关系, 31 个省份和京津冀及周边地区均处于 $\mathrm{U}$ 型的上升阶段,若不采取强有力管控措施推动 $\mathrm{NO}_{x}$ 减排, $\mathrm{NO}_{2}$ 浓度将随着经济增长出现反弹。

大气污染防治政策对于短期内推动环境空气质量与经济协调发展效果明显,但要使长期关系保持协调稳 定状态, 实现经济高质量发展和生态环境高水平保护, 关键是在经济保持稳定增长的同时, 要持续削减污染物 排放量,推动污染物浓度稳步下降。综上所述,本文提出如下建议:一是“十四五”期间要继续制定并实施新 一轮的大气污染防治行动计划, 聚焦重点区域和突出问题, 实施重大减排工程, 大力削减污染物排放, 推动环 境空气质量持续改善。二是强化 $\mathrm{NO}_{2}$ 污染治理。深人调整优化交通运输结构,加强在用车尾气监管,推广新 能源车,推动机动车等移动源 $\mathrm{NO}_{x}$ 持续减排。三是京津冀及周边地区要加大对 $\mathrm{PM}_{10}$ 污染治理力度,通过清洁 取暖改造、工业企业深度治理以及扬尘综合整治等措施,持续削减颗粒物排放。

\section{参考文献(References) :}

[ 1 ] Lu X, Zhang S J, Xing J, Wang Y J, Chen W H, Ding D, Wu Y, Wang S X, Duan L, Hao J M. Progress of air pollution control in China and its challenges and opportunities in the ecological civilization era. Engineering, 2020,6(12):1423-1431.

[ 2 ] Sun D Q, Zhang J X, Hu Y, Jiang J L, Zhou L. Spatial analysis of China's eco-environmental quality : 1990-2010. Journal of Geographical Sciences, $2013,23(4): 695-709$. 
[ 3 ] Zhang Y H,Hu M, Zhong L J, Wiedensohler A, Liu S C, Andreae M O, Wang W, Fan S J. Regional integrated experiments on air quality over Pearl River Delta 2004(PRIDE- PRD2004) : overview. Atmospheric Environment, 2008,42(25): 6157-6173.

[4] 王长春. 大气污染与经济增长关系的文献综述及对策研究.时代金融, 2018,(23):245-248.

[5]程钰, 刘婷婷, 赵云璐, 王亚平. 京津冀及周边地区 “ $2+26$ ”城市空气质量时空演变与经济社会驱动机理. 经济地理, 2019, 39 ( 10): $183-192$.

[ 6 ] Chen N, Xu L. Relationship between air quality and economic development in the provincial capital cities of China. Environmental Science and Pollution Research,2017,24(3):2928-2935.

[ 7 ] 韩瑞玲,佟连军,佟伟铭,于建辉. 经济与环境发展关系研究进展与述评. 中国人口 - 资源与环境,2012,22(02): 119-124.

[ 8 ] Grossman G M, Krueger A B. Environmental impacts of a North American free trade agreement. National Bureau of Economic Research, 1992, 8 (2) :223-250.

[ 9 ] Panayotou T. Empirical tests and policy analysis of environmental degradation at different stages of economic development. Geneva: International Labour Organization, 1993.

[10] Galeotti M, Lanza A, Pauli F. Reassessing the environmental Kuznets curve for CO2 emissions: A robustness exercise. Ecological Economics,2006, $57(1): 152163$.

[11] Bernard J T, Gavin M, Khalaf L, Voia M. The environmental Kuznets curve: tipping points, uncertainty and weak identification. Cahiers De Recherche Create,2011,60(2):285-315.

[12] Wang K M. The relationship between carbon dioxide emissions and economic growth: quantile panel-type analysis. Quality \& Quantity International Journal of Methodology, 2013,47(3):1337-1366.

[13] Jebli M B, Youssef S B, Ozturk I. Testing environmental Kuznets curve hypothesis: The role of renewable and non-renewable energy consumption and trade in OECD countries. Ecological Indicators, 2016,1(60):824831.

[14] 包群,彭水军. 经济增长与环境污染: 基于面板数据的联立方程估计. 世界经济, 2006,(11):48-58.

[15] Al-Mulali U,Saboori B,Ozturk I. Investigating the environmental Kuznets curve hypothesis in Vietnam. Energy Policy,2015,76,123-131.

[16] 胡宗义,刘亦文,唐李伟. 低碳经济背景下碳排放的库兹涅茨曲线研究. 统计研究, 2013,30(02):73-79.

[17] Wagner M. The carbon Kuznets curve: a cloudy picture emitted by bad econometrics? Resource and Energy Economics,2008,30(3):388-408.

[18] 王微微,谭咏琳. 大气污染与经济增长关系的再检验—基于门槛回归模型对 179 个地级以上城市的分组研究. 山东财经大学学报, $2019,31(05): 14-24$.

[19] Chen N, Xu L. Relationship between air quality and economic development in the provincial capital cities of China. Environmental Science and Pollution Research,2017,24(3) :2928-2935.

[20] 池建宇, 张洋,晏思雨. 城市的经济发展水平影响空气质量吗一一基于我国 31 个省会城市和直辖市的经验验证. 经济与管理, 2014,28 (05) :26-31.

[21] 李雅男,丁振民, 邓元杰,侯孟阳,姚顺波. 中国城市工业化发展与 PM2.5 的关系: 兼论 EKC 曲线形成的内在机制. 环境科学, 2020,41 (04):478-487.

[22] 邹凯波, 曹宝,张玉虎,刘晓宇,孙启宏. 中美两国大气污染与经济增长关系比较分析. 生态经济,2020,36(02):131-137.

[23] Xie Q, Xu X, Liu X. Is there an EKC between economic growth and smog pollution in China? New evidence from semiparametric spatial autoregressive models. Journal of Cleaner Production, 2019,220:873-883.

[24] Yang Z, Luo H, Wang X. Study on the relationship between air pollution and economic development. Science Discovery, 2018,6(1):12-18.

[25] 代智能,刘汇, 朱丹梅. 基于 EKC 改进模型的福建经济与大气环境质量关系分析. 厦门理工学院学报,2020,28(01):73-78.

[26] 佟惠. 基于河南省工业大气污染排放量与经济发展的 EKC 曲线实证研究. 化工管理,2017,(35):251-251,253-253.

[27] 严雅雪, 李琼琼, 李小平. 中国城市雾䨪库兹涅茨曲线的区域异质性研究. 统计与决策, 2021,37(02):60-64.

[28] 祝伟,张旭东. 人口集聚、经济增长与城市空气质量一一基于 274 个地级市数据的空间计量分析. 西北人口,2021,42( 02): $37-50$.

[29] 王西琴, 杜倩倩, 张远. 我国东中西部典型城市 EKC 曲线的阶段判断. 生态经济,2013,(05):56-60.

[30] 周茜. 中国区域经济增长对环境质量的影响——基于东、中、西部地区环境库兹涅荻曲线的实证研究. 统计与信息论坛, 2011,26(10): $45-51$.

[31] 李健,靳泽凡,苑清敏. 京津冀空气质量环境库兹涅茨曲线及影响因素——基于 2006一 2017 年面板数据的分析. 生态经济, 2019,35(02): 197-201,218-218.

[32] 吴俊良. 珠三角城市社会经济发展对颗粒物污染的影响研究 [D]. 广州: 暨南大学, 2020.

[33] 杨肃昌,马素琳. 城市经济增长对空气质量的影响——基于省会城市面板数据的分析. 城市问题,2015,(12):4-11.

[34] 谭梦薇. 经济增长与环境污染实证研究. 合作经济与科技, 2020,(16) :42-44.

[35] 陈林,肖倩冰,蓝淑菁. 基于产业结构门槛效应模型的环境政策治污效益评估一一以大污染防治行动计划》为例. 资源科学, 2021,43 
(02) :341-356.

[36] 杨晓燕,贾秋丞,孙大利, 胡永锋,吕晓剑.京津冀主要大城市经济发展中城市化与大气环境质量的关系. 岩矿测试, 2021,40(02):273-284.

[37] 高明,郭峰. 城市化对空气质量的影响研究——以京津冀城市群为例. 环境经济研究,2018,3(03):88-105.

[38] 曾翔,沈继红. 江浙沪三地城市大气污染物排放的环境库兹涅荻曲线再检验. 宏观经济研究,2017,(06): 121-131.

[39] 伍燕南,王跃. 提高空气质量指数准确性的建议. 环境科学与管理,2012,37(08): 125-128.

[40］王敏,黄港. 我国的环境污染与经济增长. 经济学(季刊),2015,14(02):557-578.

[41］国家统计局. 2020 我国统计年鉴. [2020-12-31]. http://www.stats.gov.cn/tjsj/ndsj/2020/indexch.htm.

[42] 住房和城乡建设部. 2019 年城市建设统计年鉴. [2020-12-31]. http://mohurd.gov.cn/xytj/tjzljsxytjgb/jstjnj/index.html.

[43] 刘树华,缪育聪. 京津冀雾䨪成因与治理. 中国经济报告, 2017, (02) :18-20.

[44] Grossman G M,Krueger A B. Economic growth and the environment. The quarterly journal of economics, 1995, 110(2) :353-377.

[45] He K. Multi-resolution Emission Inventory for China ( MEIC) : model framework and 1990-2010 anthropogenic emissions. AGU Fall Meeting. AGU Fall Meeting Abstracts,2012.

[46] Chen W Y,Xu R N. Clean coal technology development in China. Energy Policy, 2010,38(5):2123-2130.

[47] 柴发合. 我国大气污染治理历程回顾与展望. 环境与可持续发展, 2020,45(03):5-15.

[48] Zheng B, Tong D, Li M, Liu F, Hong C P, Geng G N, Li H Y, Li X, Peng L Q, Qi J, Yan L, Zhang Y X, Zhao H Y, Zheng Y X, He K B, Zhang Q. Trends in China's anthropogenic emissions since 2010 as the consequence of clean air actions. Atmospheric Chemistry and Physics, 2018, 18, 1409514111.

[49] 中国工程院. 大气污染防治行动计划终期评估报告. 北京: 中国工程院,2018.

[50] Feng Y Y, Ning M, Lei Y, Sun Y M, Liu W, Wang J N. Defending blue sky in China: effectiveness of the “Air Pollution Prevention and Control Action Plan” on air quality improvements from 2013 to 2017. Journal of Environmental Management, 2019,252:109603.

[51] Fu M L, Liu H, Jin X X, He, K B. National-to port-level inventories of shipping emissions in China. Environmental Research Letters, 2017, $12: 114024$

[52] Liu F, Beirle S,Zhang Q, van der A R J,Zheng B, Tong D, He K. NO ${ }_{x}$ emission trends over chinese cities estimated from OMI observations during 2005 to 2015. Atmospheric Chemistry and Physics, 2017,17:9261- 9275.

[53] Ding J, van der A R J, Mijling B, Jalkanen J P, Johansson L, Levelt P F. Maritime $\mathrm{NO}_{x}$ emissions over Chinese Seas derived from satellite observations. Geophysical Research Letters, 2018,45:2031- 2037.

[54] De Foy B, Lu Z F, Streets D G. Satellite $\mathrm{NO}_{2}$ retrievals suggest China has exceeded its $\mathrm{NO}_{x}$ reduction goals from the twelfth Five-Year Plan. Scientific Reports, 2016,6(1):35912.

［55］国务院. 中华人民共和国国民经济和社会发展第十二个五年规划纲要. [2011-03-16]. http://www. gov.cn/zhengce/content/2018-07/03/ content_5303158.htm.

[56］生态环境部. 蓝天保卫战——我国空气质量改善报告(2013-2018 年). 北京:生态环境部,2019.

[57] Zhao B, Wang S X, Liu H, Xu J Y, Fu K, Klimont Z, Hao J M, He K B, Cofala J, Amann M. $\mathrm{NO}_{x}$ emissions in China: historical trends and future perspectives. Atmospheric Chemistry and Physics, 2013,13(19):9869-9897.

[58］中国工程院.打赢蓝天保卫战三年行动计划终期评估报告. 北京: 中国工程院, 2021 . 